\title{
Research on preventive technologies for bed-separation water hazard in China coal mines
}

\author{
Herong Gui ${ }^{1}$ - Shijie Tong ${ }^{2} \cdot$ Weizhong Qiu ${ }^{3} \cdot$ Manli Lin ${ }^{1}$
}

Received: 24 July 2017 / Accepted: 5 January 2018 / Published online: 24 January 2018

(c) The Author(s) 2018. This article is an open access publication

\begin{abstract}
Bed-separation water is one of the major water hazards in coal mines. Targeted researches on the preventive technologies are of paramount importance to safe mining. This article studied the restrictive effect of geological and mining factors, such as lithological properties of roof strata, coal seam inclination, water source to bed separations, roof management method, dimensions of mining working face, and mining progress, on the formation of bed-separation water hazard. The key techniques to prevent bed-separation water-related accidents include interception, diversion, destructing the buffer layer, grouting and backfilling, etc. The operation and efficiency of each technique are corroborated in field engineering cases. The results of this study will offer reference to countries with similar mining conditions in the researches on bed-separation water burst and hazard control in coal mines.
\end{abstract}

Keywords Bed-separation water · Influencing factors $\cdot$ Interception and diversion · Destruction of the buffer layer $\cdot$ Filling the bed separation void by grouting

\section{Introduction}

China is the world's largest coal producer (e.g., in 2016, China's coal production was 1685.7 MTOE ("MTOE" is the abbreviation of million tons of oil equivalent), while only 364.8 MTOE by the US, 299.3 MTOE by Australia, 288.5 MTOE by India, 255.7 MTOE by Indonesia, 192.8 MTOE by Russia, 142.4 MTOE by South Africa, and 52.3 MTOE by Poland according to the 'BP Statistical Review of World Energy 2017), as well as a victim to mining accidents and disasters due to heavy coal mining. Among the five major coalmine hazards (water burst, gas explosion, coal spontaneous combustion, roof caving, rock and coal dust pollution), water is the most destructive of all (Gui et al. 2016).

Herong Gui

guiherong@163.com

1 National Engineering Research Center of Coal Mine Water Hazard Controlling, Suzhou University, Suzhou 234000, Anhui, China

2 Wolonghu Coalmine of Wanbei Coal-Electricity Group Co. Ltd, Suzhou 234000, Anhui, China

3 No. 115 Prospecting Institute of Coal Geology of Shanxi Province, Datong 037000, Shanxi, China
China has vast coal-bearing land, expanding across complicated geological and hydrological conditions under the exposure to multiple water hazards. Over 30 types of water hazards have been documented in China coal mines (Gui and Lin 2016), including water burst from roof and bottom aquifer and karst collapse pillars. Roof bed-separation water hazard, emerged only recently, has quickly attracted close attention due to its frequency of occurrences and severity of losses incurred. On May 21, 2005, the No.745 working face of Huaibei Haizi Coal mine, Anhui Province, was struck by a bed-separation water accident. Water flow topped at $3887 \mathrm{~m}^{3} / \mathrm{h}$, killing five miners. On January 30,2015 , a bedseparation water accident attached the No. 866-1 mining face of Huaibei Zhuxianzhuang Coal mine. Water discharge maximized at $7200 \mathrm{~m}^{3} / \mathrm{h}$. In addition to huge economic losses, seven people died and seven others seriously injured.

Mining activities disrupt the stress and strain balance in the roof rocks and drive them to slide downward. Under normal conditions, the roof rock is composed of rock strata with varying thicknesses and hardnesses. As mining proceeds, the strata move down at different speeds, creating a void called bed separation. In its definition, bed separation is also expressed by the deflection difference of the two contiguous strata. The underground water accumulated in the bed-separation void is thus called bed-separation water 
(Gui et al. 2017). The consequences of bed-separation water accidents would range from production halt to geological calamities such as rock burst, further resulting in equipment destruction and human casualties. Therefore, the formation of bed separation water and hazard control are now closely studied by Chinese mining experts.

The conventional theory of rock movement divided the deformed roof rock, the strata from the goaf area up to the ground surface, into three layers (i.e. the upper three zones): caving zone, water-conductive fissure zone, and bending zone. As mining technologies and theoretical researches developed, the theory of rock movement has been further refined with an addition of bed-separation zone to the upper three zones (Tan et al. 2010). Empirical experiences obtained from extensive field monitoring and observations from simulations and calculations have shown that the presence of thick-hard strata in the roof strata is the precondition for bed separations to develop. In effect, bed separations can only grow to the extent bound by the thick-hard strata, which is, therefore, named as the key strata (Qian et al. 1996). Researches in this regard provided the theoretical rationale for the identification of bed separations and bed-separation water, as well as effective containment of bed-separation water hazard. Since the 1980s, grouting has been the main preventive measure against bed-separation water hazard. It was first tested successfully in more than a dozen coal mines, such as Fushun Laohutai Coalmine of Liaoning Province and Datun Xuzhuang Coalmine of Jiangsu Province (Chen and Guo 2008; Xuan and Xu 2014; Xuan et al. 2014; Yan et al. 2016), and then promulgated nationally. Later on, new techniques were introduced to treat bed-separation water, such as diversion and interception. The toolkit to treat bedseparation water hazard are further completed in China $(\mathrm{Xu}$ et al. 2013; Tan et al. 2013; Xing et al. 2015).

\section{Influencing factors in the formation of bed-separation water}

The features of bed-separation water hazard in coal mines show a strong correlation between the hazard formation and the geological and mining factors. A clear understanding of how these factors paly a role in the formation of bed separation and water logging is the primary premise to effectively treating and containing bed-separation water hazards.

\section{Geological factors}

The geological factors contributing to the formation of bedseparation water hazards include lithological properties of the roof rock, slant angle of coal seam, and source of water to bed separation.
1. Lithological properties of the roof rock. The roof rock over the coal seam is composed of strata of varying thicknesses and hardnesses. Under mining activities, the thick-hard rock strata (i.e., the key strata) play the key role to the subsidence and movement of the roof rock. Its high tensile strength and deflection difference from the underlying weak strata allow bed separations to form close to the goaf area, within the caving zone and fissure zone, or away from the goaf area, in the bending zone (Fig. 1). The former, connected to the goaf area, allows timely draining of excess water and effectively mitigates bed-separation water hazard. The latter is usually separated from the fissure zone by a buffer layer (thickness of $h_{0}$ in Fig. 1), which severs as the hydraulic connection between the bed-separation water and the caving and fissure zone. If the hydrostatic pressure of the bed separation water rises, coupled with rock burst caused by the rupture of the upper thick-hard strata, the bed separation water will crash through the buffer layer almost instantly and rush into the goaf area, an immediate threat to mining safety. As a result, the bed separations and bed-separation water which are emplaced above water-conductive fissure zone and in the lower part of bending zone are called "disastrous bed separations" and "disastrous bed-separation water".

2. Slant angle of coal seam. The slant angle of coal seam determines the shape of the bed separation and the maximum bed-separation height. When the coal seam is horizontal or near-horizontal, bed separation would be in the shape of a regular basin (bed separation height is larger in the middle than on the sides, as in Fig. 1). Maximum bed-separation height usually develops in the

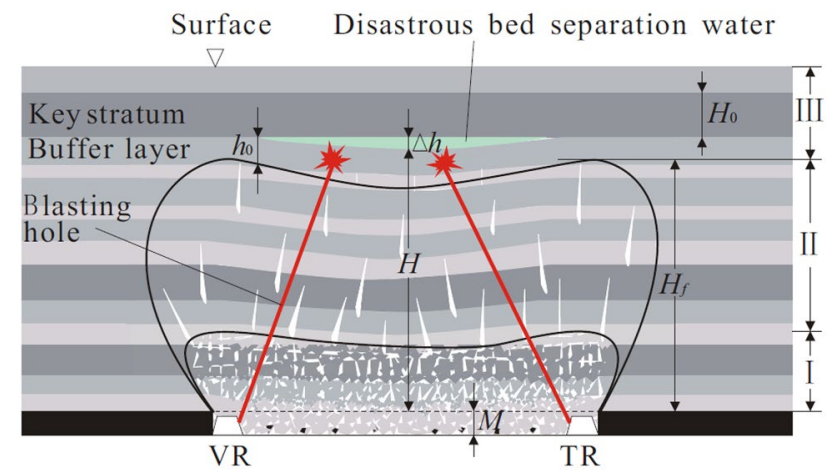

$\triangle h$-Max height of bed separation/ $\mathrm{m}$; I - Caving zone ; II -Fractured zone; III-Bending zone; $h_{0}$ - Thickness of buffer layer/m; $H_{0}$-Thickness of key stratum $/ \mathrm{m}$; $H_{f}-$ Max height of fractured zone/m; $H$-Height from the bed separation bottom to the roof of coal seam $/ \mathrm{m}$; $M$-Mining height; VR-Ventilation roadway; TRTransportation roadway

Fig. 1 Diagram of disastrous bed separation 


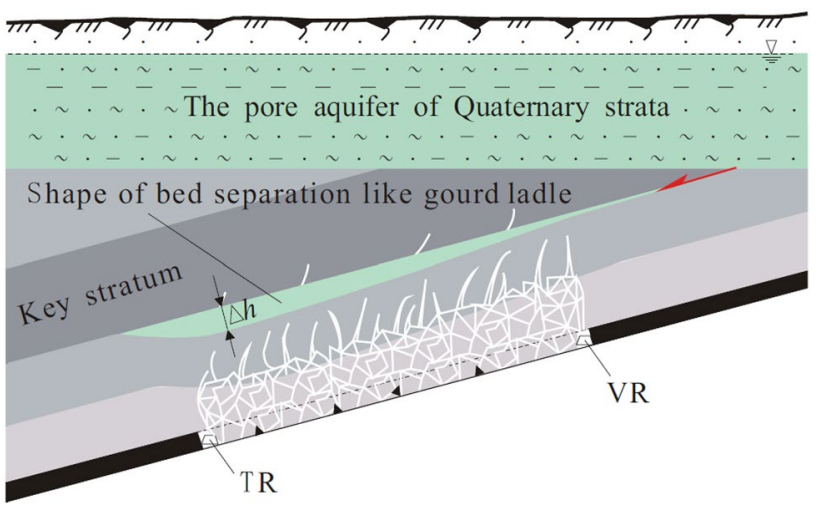

Fig. 2 Diagram of bed separation when mining on inclined coal seam

middle of the goaf zone. As the angle increases, the bed separation develops in the shape of a gourd ladle (Fig. 2). Maximum bed separation height is located away from the middle of the goaf zone and grows along down the slope.

3. Source of water to the bed separation. Bed separation provides potential reservoir space for underground water. Water supply determines the volume of water and hydrostatic pressure in the bed separation. Generally, the underground water in the strata above the bed separation is the direct water source, which quickly fills up the bed-separation void under the negative pressure, thus driving up the water pressure in the bed separation up to the level in the upper strata (apparently, if the upper strata are insufficiently water abundant, the bed separation would not be filled up and bedseparation water pressure would not rise to that in the upper strata). In addition to direct water source, there would be indirect source of water (such as the Quaternary pore aquifer) that replenishes the bed separation through inter-stratum fissures or water-conductive structure.

\section{Mining factors}

The mining factors in the formation of bed-separation water hazards include rooftop management method, dimensions of the working face, mining height, and progression speed, etc.

1. Rooftop management method. Longwall mining is commonly engineered in China coal mines, where fullcaving is usually applied for rooftop management. Due to the caving of the direct roof and old roof, as well as the cyclical variations of mining pressure, the bed separation in the bending zone forms and develops to the maximum, and closes when the key strata fracture, making up of a rhythmic pattern.

2. Dimensions of the working face. (i) The bed-separation height is positively correlated to the mining height, meaning the larger the mining height, the bigger the bed-separation height. Through numerical simulations, the maximum bed-separation height $(\Delta h)$ is linear to the mining height $(M)$ (Fig. 3):

$\Delta h=0.5779 M+0.2729 \quad(M=2-8 \mathrm{~m})$.

In addition, Fig. 3 also shows that when mining height $(M)$ is between 2 and $6 \mathrm{~m}$, the ratio, $\eta$, of bed-separation height and mining height $(\Delta h / M)$ increases faster, while it increments slower when mining height is between 6 and $8 \mathrm{~m}$. Equations (2) and (3) demonstrate the relationship between $\eta$ and $M$.

$$
\begin{aligned}
& \eta_{1}=0.004 M^{2}-0.013 M+0.475 \quad(M=2-6 \mathrm{~m}), \\
& \eta_{2}=0.0044 M+0.5066 \quad(M=6-8 \mathrm{~m}) .
\end{aligned}
$$

(ii) The strike length and slope width of the working face are also factors in bed-separation formation. Generally, larger strike length and slope width on the working face correspond with wider bed separation. With all other things equal, if the working face broadens along its strike, the bed separation has the tendency to close up and thus shorter lifespan, which is an adverse condition for water accumulation. On the contrary, if the working face tapers along its strike, the bed separation is much restricted and remains longer, or even stays open much longer, conducive for water accumulation and posing greater threat.

3. Speed of mining progress. The lifespan of bed separation $(T)$ is inversely correlated to mining speed $(v)$, as in Eq. (4) (Qiao et al. 2011).

$$
T=k \frac{H_{0}}{v} \sqrt{\frac{R_{t}}{q}},
$$

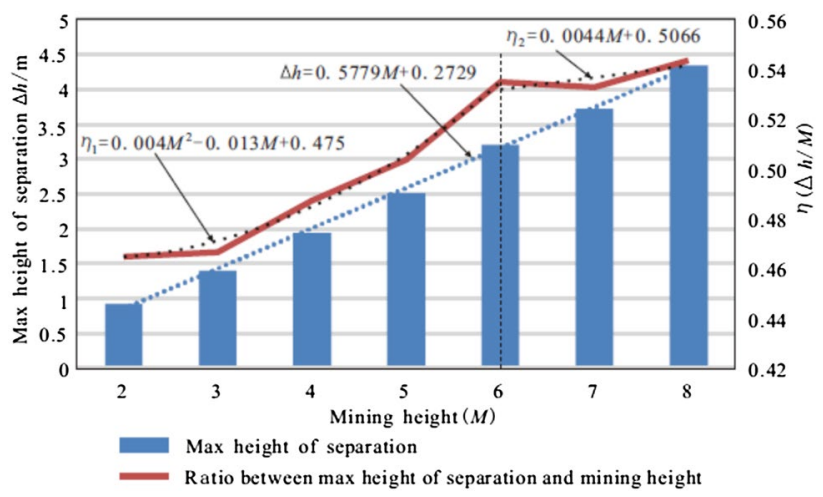

Fig. 3 Relations between the maximum bed-separation height $(\Delta h)$, mining height $(M)$, and ratio between the two 
where $T$-lifespan of bed separation/day; $H_{0}$-thickness of the key strata/m; $v$-mining speed $/ \mathrm{m} \mathrm{d}^{-1} ; R_{t}$-tensile strength of the key strata/MPa; $q$-load on the upper strata of the key strata/MPa; $k$ - coefficient.

Empirical experiences have shown that slower mining prolongs the lifespan of bed separations, conducive to water accumulation. In comparison, maintaining a constant mining speed shortens the lifespan of bed separation, lowering water level and hydrostatic pressure, effectively mitigating hazards of bed-separation water burst.

\section{Preventive techniques and countermeasures}

Building on the understanding of the formation mechanism of bed separations, bed separation water, and the analysis of the influencing factors, the main technologies to treat bed separation water in China coal mines include: (1) cutting off source of water to bed separations (interception) and draining bed-separation water (diversion); (2) breaking the buffer zone; (3) grouting and backfilling the bed-separation void, etc.

\section{Interception and diversion}

1. Interception. To start by first analyzing the formation conditions of the disastrous bed-separation water (which develops in the lower part of the bending zone and above the fissure zone). If there is an indirect water source, then cut off water supply by grouting the conduits once identified. As in Fig. 4, to intercept the underground water in the Quaternary pore aquifer as a water source, a grouting spot is built on the ground surface, where to drill and grout directionally at long distance to the branch drills (SLG, Fig. 4c) and fully seal up the feeding channels.

2. Diversion. To neutralize the threat of developed disastrous bed-separation water, it is doable to artificially create hydraulic links between the bed-separation water and caving zone by making diverting drills on the ground or underground (see Fig. 4a, b).

(i) Ground-diversion drillings $\operatorname{SD}_{i}(i=1,2, \ldots)$ cut through the buffer layer beneath the bed-separation water and divert the water into the caving zone. (ii) On the underground working face, diversion drillings $\operatorname{MD}_{j}(j=1,2, \ldots)$ in the ventilation roadway (VR), transportation roadway (TR), or the special discharge tunnel to drain the bed-separation water. In recent years, when mining under highly dangerous water abundant and thick aquifers, long-distance directional drills $\operatorname{MLD}_{k}(k=1,2, \ldots)$ underground can be applied to drain bed-separation water, generating favorable effects.

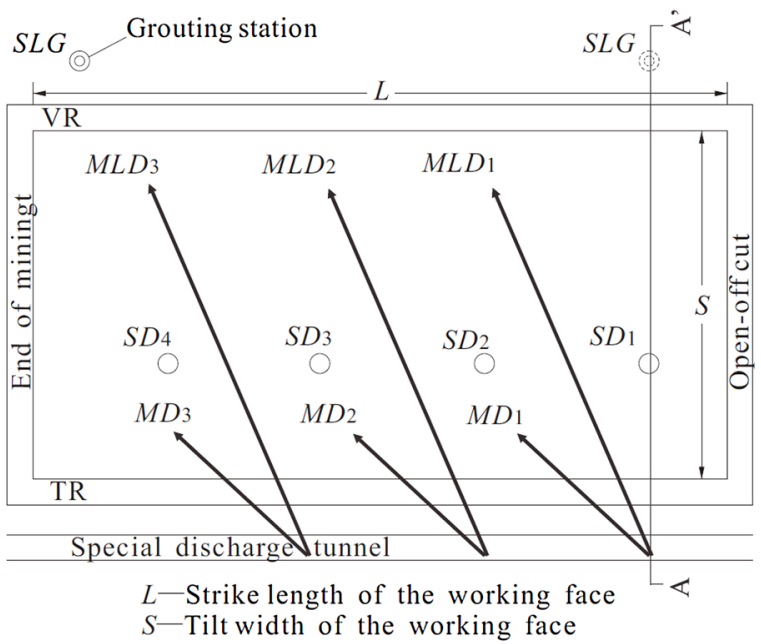

(a) Plan

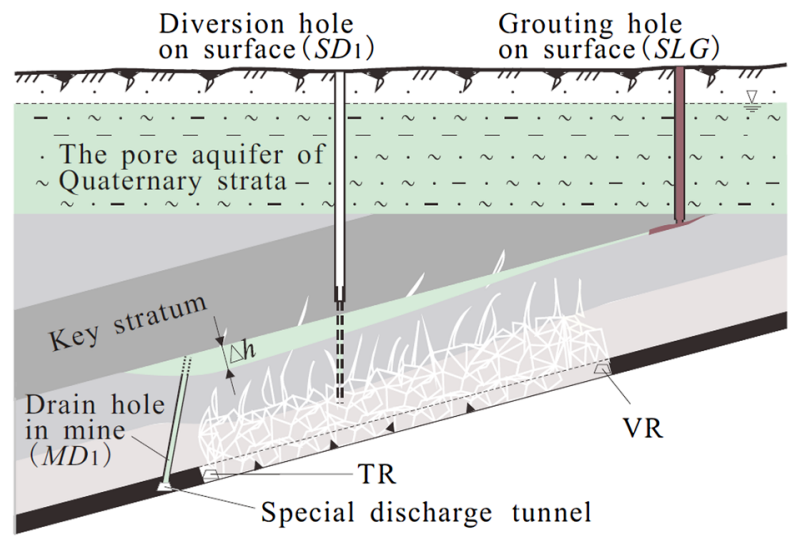

(b) Section of $A-A$ '

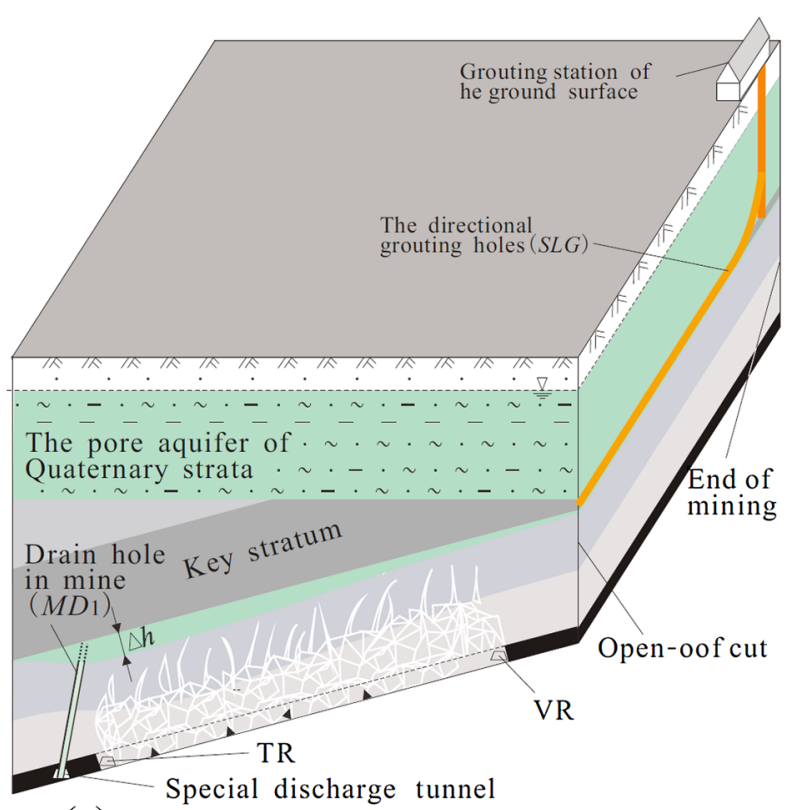

(c) Stop up the channel to water source by grouting

Fig. 4 Diagram of interception and diversion 
3. Engineering cases. At Yuhua Coalmine, Jiaoping of Shaanxi, there were 24 underground diversion drills on the no. 1418 working face. In 12 months, a total of $430,000 \mathrm{~m}^{3}$ water was discharged (Yin and Tian 2015), eliminating the bed-separation water hazard. At Hongliu Coalmine, Yuanyang Lake of Ningxia, 14 long-distance directional drills (water discharge at $216 \mathrm{~m}^{3} / \mathrm{h}$ per drill, an average of $49.9 \mathrm{~m}^{3} / \mathrm{h}$ ) were plotted to alleviate hazards of fissure water and bed-separation water on the I 030201 fully mechanical working face (Tian 2013). A total of $360,000 \mathrm{~m}^{3}$ of water was discharged (approximately $79 \%$ of the total water reserve), safeguarding mining safety on the working face.

\section{Breaking the buffer layer}

1. Critical thickness of the buffer layer $\left(h_{\mathrm{c}}\right)$. Under disastrous bed-separation water, there is bound to be a buffer layer $\left(h_{0}\right.$ in Fig. 1$)$, which preserves water to accumulate in the bed separation. Hence, stability of the buffer layer is a critical factor to bed-separation water burst. Thicker buffer layer is stronger against pressure (hydrostatic pressure of the bed-separation water and the impact of the key strata rupture) as well as against bed-separation water burst. The water-burst coefficient $\left(T_{\mathrm{b}}\right)$ is defined as:

$$
T_{\mathrm{b}}=\frac{P}{h_{0}},
$$

where $T_{\mathrm{b}}$-water-burst coefficient of the buffer layer/ $\mathrm{MPa} \mathrm{m}^{-1}$; $P$-bearing capability of the buffer layer/ MPa (only hydrostatic pressure of the bed-separation water is considered); $h_{0}$-thickness of the buffer layer, $h_{0}=H-H_{\mathrm{f}}$ (See Fig. 1).

According to the Regulations on Coal mine Water Control, water-burst coefficient is generally no more than $0.06 \mathrm{MPa} / \mathrm{m}$. Hence, the critical thickness of the buffer layer $\left(h_{\mathrm{c}}\right)$ is:

$h_{\mathrm{c}}=\frac{P}{T_{\mathrm{bc}}}=\frac{P}{0.06}$,

where $T_{\mathrm{bc}}$-critical water burst coefficient $/ \mathrm{MPa} \mathrm{m}^{-1}$, taking $0.06 \mathrm{MPa} / \mathrm{m}$.

If $h_{0}>h_{\mathrm{c}}$, the buffer layer is strong enough to hold against bed-separation water burst. On the contrary, if $h_{0} \leq h_{\mathrm{c}}$, the buffer layer is weak, exposing potential bed-separation water hazards.

For bed-separation water in a precarious status, it is possible to pre-blast the buffer layer at TR and VR to avoid abruptive burst of bed-separation water (the blasting holes shown in Fig. 1 by the red arrow). It is on one hand to release bed-separation water, while on the other, buffer layer is thus more ductile and more of a cushion to absorb the rupture impact of the key strata, thus reducing the rock pressure on the roadways and working face.

2. Engineering case. Over the past two decade, there had been a number of incidents of bed-separation water inrush in Qidong Coalmine of Huaibei coalfield, Anhui province. The most serious disaster occurred on November 5, 2001, and the maximum water inrush volume was $1520 \mathrm{~m}^{3} / \mathrm{h}$, flooding the whole mine.

38 blasting holes (with the elevation angle of $40^{\circ}-50^{\circ}$ and the depth of 25-30 m) were deployed in the transportation roadway of no. 7,21 working face in Qidong Coalmine to blast the key strata and the buffer layer in the overlying roof rock, effectively bringing the roof bed-separation under control. No roof bed-separation water-inrush hazard had occurred before the face mining was completed.

\section{Grouting the bed-separation void}

\section{Purpose of grouting}

Grouting the bed-separation void as a treatment technique was first proposed and utilized by Polish scholars but first patented by the former Soviet counterparts. This technique was brought and promulgated in China coal mines since 1985 (Yang 2002). When it was applied in Fushun coalmines of Liaoning, it not only greatly reduced the occurrences of bed-separation water burst but also efficiently curbed ground subsidence (lowered by 36-65\%).

The effects of grouting are three-folded: (1) to cut off supply to bed-separation water and prevent water logging; (2) to bolster the key strata and alleviate rock pressure incurred by rupture of the key strata; (3) to reduce ground subsidence.

Generally, bed separations developed in the caving zone and fissure zone closer to the goaf area do not require grouting and backfilling treatment. Bed separation at a great distance from the goaf area (such as the bed separation in the mid or upper part of the bending zone) contains less-threatening water log, making grouting and backfilling unnecessary (unless ground subsidence demands such treatment). For disastrous bed separation (i.e., the bed separation in the lower part of the bending zone, which is over the fissure zone), grouting and backfilling is imperative.

Summarizing from past experiences in grouting in China coal mines, the effects are dependent on placements of drills and timing, as well as the grouting parameters. 
2. Placements of grouting holes and grouting schedule

The lifespan of bed separation is a dynamic process from formation, development, and stabilizing to closing up. Grouting is often executed in the formation stage. To obtain the optimal effects, it is best to grout before the bed separation height reaches the maximum and before the key strata rupture, which are the two critical factors when determining the desired location of drills and timing of grouting.

(i) Emplacement of the maximum bed-separation height. Previous analysis shows that, on the cross-section of the working face, if the coal seam is horizontal or near-horizontal (with a slant angle less than or equal to $10^{\circ}$ ), the maximum bed-separation height will be in the middle of the goaf zone (Fig. 1). If the coal seam is slanted at an angle, bed-separation height maximizes from the middle of the goaf zone and grows along down the slope (Fig. 2).

(ii) Time of key strata rupture. The rupture in question can be categorized as the first rupture and periodic ruptures. The first rupture usually coincides with the first wave of rock pressure on the working face. Periodic ruptures are aligned with cyclical waves of rock pressure. Therefore, the formulas for broken lengths in the first rupture $\left(L_{0}\right)$ and periodic ruptures $\left(L_{\mathrm{c}}\right)$ can be derived based on the beam theory:

$L_{0}=H_{0} \sqrt{\frac{2 R_{\mathrm{t}}}{q}}$,

$L_{\mathrm{c}}=H_{0} \sqrt{\frac{2 R_{\mathrm{t}}}{3 q}}$,

where $H_{0}$-thickness of the key strata/m; $R_{\mathrm{t}}$-tensile strength of the key strata/MPa; $Q$-load on the key strata and the overlying roof rock/MPa.

Statistics of broken lengths of mining-related key strata rupture provides ranges for first rupture $L_{0}$ of $45-60 \mathrm{~m}$ and periodic rupture $L_{\mathrm{c}}$ of $15-30 \mathrm{~m}$.

Furthermore, when planning a grouting task for neighboring or nearby working faces, it is advisable to select a suitable location for ground grouting station (Fig. 5). In line with the location of maximum bed-separation height and timing of key strata rupture, to determine the positions of grouting holes and grouting schedule. A highpressure grouting pump is used to fill and grout the bedseparation void through the feeding pipe and grouting holes. It is both effective and cost-efficient.

3. Technicalities for grouting

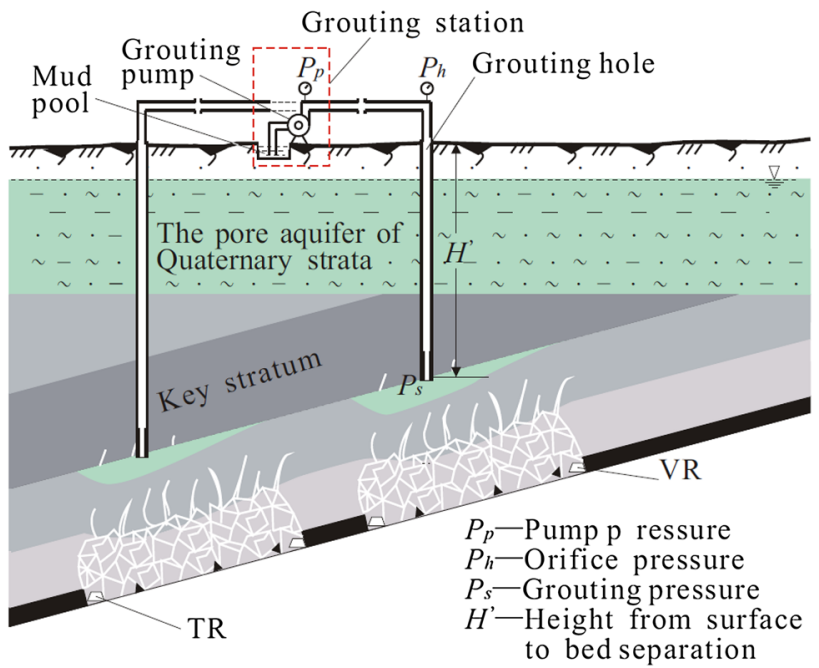

Fig. 5 Diagram of grouting technique

The major technical parameters for bed-separation grouting include grouting materials, grouting pressure, and grouting amount.

(i) Grouting material. In China, fly ash is usually used as grouting materials. There are four physical forms of fly ash: dry fly ash (unit weight of $1.85-1.87 \mathrm{t} / \mathrm{m}^{3}$ ), fly ash pulp (unit weight of $1.12-1.18 \mathrm{t} / \mathrm{m}^{3}$, water/volume ratio of $76-82 \%$ ), saturated water-ash mixture (unit weight $1.54-1.56 \mathrm{t} / \mathrm{m}^{3}$, water/volume ratio of 35.8-36.5\%), and compressed wet ash mixture (unit weight $1.64-1.66 \mathrm{t} / \mathrm{m}^{3}$, water/volume ratio of $24.0-24.7 \%$ ). In the grouting process, the selection of the physical forms of fly ash as grouting material is based on factors including grouting pressure, bed separation volume, and slant angle of the coal seam.

Through past grouting experiments, it is proven effective to use fly ash pulp with unit weight of $1.12-1.14 \mathrm{t} / \mathrm{m}^{3}$ under normal grouting pressure, while use fly ash with unit weight of $1.14-1.16 \mathrm{t} / \mathrm{m}^{3}$ under zero or negative pressure.

(ii) Grouting pressure. According to Fig. 5, grouting pressure $P_{\mathrm{s}}$ equals to:

$P_{\mathrm{s}}=P_{\mathrm{p}}+\gamma_{\mathrm{s}} \mathrm{H}^{\prime}-\mu_{\mathrm{f}}$,

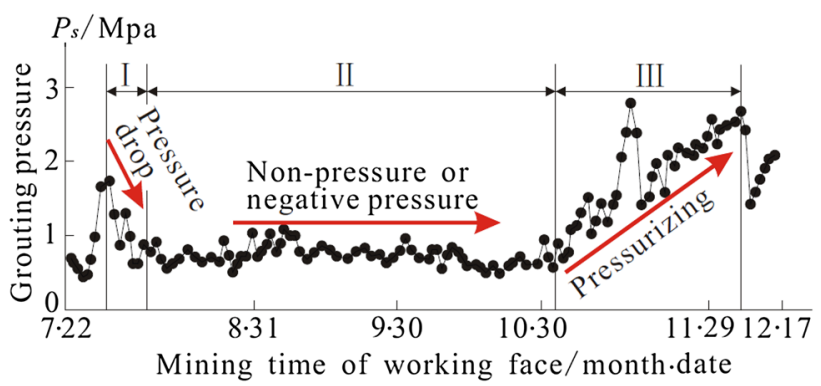

Fig. 6 Changes of grouting pressure 
Table 1 Subsidence-reducing coefficient and grouting amount

\begin{tabular}{|c|c|c|c|c|c|c|c|c|c|c|}
\hline \multirow[t]{2}{*}{$\begin{array}{l}\text { Mining } \\
\text { face }\end{array}$} & \multirow[t]{2}{*}{$\begin{array}{l}\text { Thick- } \\
\text { ness of coal } \\
\text { seam }(\mathrm{mm})\end{array}$} & \multirow[t]{2}{*}{$\begin{array}{l}\text { Slant angle of } \\
\text { coal seam }\left(^{\circ}\right)\end{array}$} & \multicolumn{2}{|c|}{$\begin{array}{l}\text { Mining face dimen- } \\
\text { sions }\end{array}$} & \multirow[t]{2}{*}{$\begin{array}{l}\text { Mining } \\
\text { depth } \\
\text { (m) }\end{array}$} & \multirow[t]{2}{*}{$\begin{array}{l}\text { Est. max. } \\
\text { subsidence } \\
(\mathrm{mm})\end{array}$} & \multicolumn{2}{|c|}{$\begin{array}{l}\text { Grouting } \\
\text { amount } \\
\left(10^{4} \mathrm{~m}^{3}\right)\end{array}$} & \multirow[t]{2}{*}{$\begin{array}{l}\text { Act. subsidence } \\
\text { after grouting } \\
(\mathrm{mm})\end{array}$} & \multirow[t]{2}{*}{$\begin{array}{l}\text { reducing coeffi- } \\
\text { cient after grouting } \\
(\%)\end{array}$} \\
\hline & & & $\begin{array}{l}\text { Strike } \\
\text { length } \\
\text { (m) }\end{array}$ & $\begin{array}{l}\text { Slope } \\
\text { length } \\
(\mathrm{m})\end{array}$ & & & Est. & Act. & & \\
\hline 514 & 25.70 & 26 & 427 & 120 & 602 & 2046 & 5.42 & 3.62 & 712 & 65.20 \\
\hline 510 & 36.60 & 30 & 345 & 82 & 619 & 3240 & 5.47 & 4.05 & 1118 & 65.49 \\
\hline 511 & 27.30 & 28 & 415 & 85 & 621 & 2254 & 4.97 & 3.90 & 843 & 62.60 \\
\hline
\end{tabular}

where $P_{\mathrm{p}}$ - pressure in grouting pump/MPa; $\gamma_{\mathrm{s}}$ —unit weight of fly ash pulp/MPa m ${ }^{-1} ; H^{\prime}$-depth of bed separation (from its roof to ground surface) $/ \mathrm{m} ; \mu_{\mathrm{f}}$-resistance in feeding pipe/ $\mathrm{MPa}$.

In the grouting process, the pressure $\left(P_{\mathrm{s}}\right)$ changes in three stages (Fig. 6) (Gao et al. 2004), from initial drop (I), to zero or negative pressure (II), and to gradual pick-up (III). When the bed separation is in its early development, $P_{\mathrm{s}}$ is relatively higher (but with smaller grouting amount). As the bed separation develops, $P_{\mathrm{s}}$ decreases to zero, while grouting amount increases. If, at this stage, grouting is at a speed slower than the bed-separation development, the pressure would be negative. When bed separation reaches the maximum, grouting has almost closed up the bed separation and the pulp is confronted with high resistance, thus driving up $P_{\mathrm{s}}$.

(iii) Grouting amount. The amount of grouting varies in accordance with purposes.

(a) If the purpose is to prevent bed-separation water burst and rock burst, grouting amount is dependent on the spatial volume of the bed separation $(V)$. For a mining working face ( $L$ for length and $\mathrm{S}$ for the slope width), on its cross-section, $Y_{1}(x)$ stands for the deflection curve of upper rock strata over the bed separation and $Y_{2}(x)$ for the deflection curve of upper rock strata under the bed separation, the spatial volume of the bed separation can be calculated based on strata movement theory (Gao et al. 2001):

$V=L \int_{0}^{\mathrm{s}}\left[Y_{2}(x)-Y_{1}(x)\right] \mathrm{d} x$

(b) If the purpose is to reduce ground subsidence, grouting amount can be calculated based on the coefficient of subsidence reducing (Yang et al. 2001):

$V_{\mathrm{s}}=\zeta_{1} V_{\mathrm{d}}$

$V_{\mathrm{d}}=W_{\text {max }} a b$,

where $V_{\mathrm{s}}$-volume of all the fly ash grouted $/ \mathrm{m}^{3} ; \zeta_{1}$-coefficient of subsidence-reducing (i.e., the ratio between the reduced subsidence by grouting to the estimated maximum subsidence; $W_{\max }$-maximum ground subsidence; $a$-strike length of the ground subsidence basin/m, $a=a_{\mathrm{c}}-s_{0}, a_{\mathrm{c}}$ is the calculated strike length of the subsidence basin, $s_{0}$ is the strike deviation from the inflection point $/ \mathrm{m} ; b$ - dip length of the ground subsidence basin/m, $a=a_{\mathrm{c}}-s_{0}, a_{\mathrm{c}}$ is the calculated dip length of the subsidence basin, $s_{0}$ is the dip deviation from the inflection point $/ \mathrm{m}$;

The value of $s_{0}$ and $s_{1}$ is usually taken in the range of $0.1-0.2 H^{\prime \prime}$ ( $H^{\prime \prime}$ is the mining depth/m)

If the fly ash pulp is made of water and ash in the ratio of $2: 1$, then the total volume of the pulp grouted is $3 V_{\mathrm{s}}$. Due to the irregular shape of the bed separation, the total grouting amount shall be multiplied by $\zeta_{2}$, the distributional pattern coefficient of the bed separation (usually 0.3-0.7). Therefore, the end product of the total grouting amount is:

$V_{\mathrm{s}}^{\prime}=3 \zeta_{1} \zeta_{2} a b W_{\max }$

(iv) Engineering case. In the three mining working faces in Fushun Laohutai Coalmine of Liaoning (Table 1) (Yang et al. 2001), the estimated ground subsidence is 2254-3240 mm, the targeted coefficient of subsidence reducing is $60-65 \%$. The fly ash pulp is made of water and ash in the ratio of $2: 1$. According to Eq. (13), the calculated grouting amount is $49,700-54,700 \mathrm{~m}^{3}$. After grouting, field measurement showed that the ground subsided by $712-1118 \mathrm{~mm}$ and coefficient of subsidence reducing of $62.60-65.49 \%$. There was no occurrence of bed-separation water burst, substantiating the effects in subsidence reduction and disaster alleviation.

\section{Conclusions}

Following conclusions can be drawn from the above analysis.

1. The formation of bed-separation water hazards is closed related with geological and mining factors. From geological perspective, the lithological properties of the 
roof strata are the main constrains of the emplacement of the bed separation. The slant angle of coal seam is the deciding factor of the shape of the bed separation and the emplacement of the maximum bed-separation height. The water source to the bed-separation water will have an impact on the water volume and hydrostatic pressure in the bed separation. Among mining factors, when full-caving rooftop management is applied, the lifecycle of bed separation, from formation, development to maturity, is largely constrained by the cyclical rock pressure. Mining height is positively correlated to bed separation height. The strike length and slope width of the mining working face will determine the lifespan of the bed separation. Mining at a constant speed can slow down water accumulation in the bed separation.

2. Major techniques to prevent and treat bed separation water hazards: (i) Interception. From at a long distance, grouting through directional branch drills to fully block off the water-conductive channels between the water source and the bed separation. (ii) Diversion. Drilling on/under ground to drain bed separation water into the caving zone. (iii) Breaking the buffer layer. By pre-blasting the weak buffer layer before mining to create more aqueducts, through which the bed separation water is deconcentrated and drained through caving zone. (iv) Grouting and backfilling the bed-separation void to lower the likelihood of bed-separation water burst and contain ground subsidence. (v) Properly configuring the dimensions of the mining working face and planning a measured mining progress, etc.

Acknowledgements This article is funded by National Natural Science Foundation of China (41373095), Research Project of Wanbei CoalElectricity Group Co. Ltd (2017) and Practical and Innovative Project of Coal Geology Bureau of Shanxi Province (2017)

Open Access This article is distributed under the terms of the Creative Commons Attribution 4.0 International License (http://creativecomm ons.org/licenses/by/4.0/), which permits unrestricted use, distribution, and reproduction in any medium, provided you give appropriate credit to the original author(s) and the source, provide a link to the Creative Commons license, and indicate if changes were made.

\section{References}

Chen SG, Guo H (2008) Numerical simulation of bed separation development and grout injecting into separations. Geotech Geol Eng 26(4):375-385

Gao YF, Deng ZY, Yang ZD, Li WC, Xie HR (2001) Theoretical research about reduce surface subsidence by grouting in overburden bed-separations. Mine Press Roof Manage 4:65-67 (in Chinese)

Gao YF, Niu XL, Liao JZ (2004) Analysis on grouting pressure when grouting in overburden bed-separations in mine. Chin J Rock Mechan Eng 23(Suppl. 2):5244-5247 (in Chinese)

Gui HR, Lin ML (2016) Types of water hazards in China coalmines and regional characteristics. Nat Hazards 84(2):1501-1512

Gui HR, Reddy DV, Sun LH (2016) A review of technological development in water hazards control in China coalmines. Int J Earth Sci Eng 9(5): 1863-1868

Gui HR, Lin ML, Song XM (2017) Features of separation water hazard in China coalmines. Water Pract Technol 12(1):146-155

Qian MG, Miao XX, Xu JL (1996) Theoretical study of key stratum in ground control. J China Coal Soc 21(3):225-230 (in Chinese)

Qiao W, Li WP, Li XQ (2011) Mechanism of "hydrostatic waterinrush" and countermeasures for water inrush in roof bed separation of a mining face. J Mining Safety Eng 28(1):96-104 (in Chinese)

Tan YL, Zhao TB, Xiao YX (2010) Researches on floor stratum fracturing induced by anti-procedure mining underneath close-distance goaf. J Min Sci 46(3):250-259

Tan YL, Yu FH, Chen L (2013) A new approach for predicting bedding separation of roof strata in underground coalmines. Int J Rock Mech Mining Sci 61:183-188

Tian WH (2013) Formation and application of the "Quaternity" prevention measures for water disasters in fully mechanized face roof abscission layer. Shenhua Sci Technol 11(5):27-31 (in Chinese)

Xing ML, Li WP, Wang QQ, Yang DD (2015) Risk prediction of roof bed-separation water inrush in a coal mine, China. Electron J Geotech Eng 20(1):301-312

Xu ML, Zhu XG, Zhao DS (2013) Study on surface subsidence and separation range thick seam mining of daping mine. Adv Mater Res 742:268-271

Xuan DY, Xu JL (2014) Grout injection into bed separation to control surface subsidence during longwall mining under villages: case study of Liudian Coal Mine, China. Nat Hazards 73(2):83-906

Xuan DY, Xu JL, Zhu WB (2014) Dynamic disaster control under a massive igneous sill by grouting from surface boreholes. Int $\mathrm{J}$ Rock Mech Min Sci 71:176-187

Yan H, He FL, Yang T, Li LY, Zhang SB, Zhang JX (2016) The mechanism of bedding separation in roof strata overlying a roadway within a thick coal seam: a case study from the Pingshuo Coalfield, China. Eng Fail Anal 62:75-92

Yang L (2002) Re-understand the technology of reducing the subsidence due to mining by injecting grouts into separated beds in overlying disrupted strata by extraction. J China Coal Soc 27(4):353-356 (in Chinese)

Yang Y, Fan XL, Yang L, Zhao DS (2001) Research on the calculation of grout amount of harnessing the surface subsidence by injecting clay grouts into separated strata. Chin J Geol Hazard Control 12(1):78-81 (in Chinese)

Yin XW, Tian SW (2015) Research on the roof abscission layer water disaster in Yuhua Coal Mine of Jiaoping Mining Area. Shaanxi Coal 1:19-21 (in Chinese)

Publisher's Note Springer Nature remains neutral with regard to jurisdictional claims in published maps and institutional affiliations. 